\title{
Utilization of Guazuma ulmifolia gum and sodium alginate to form protective beads of antioxidant peptides obtained from Phaseolus lunatus
}

\author{
David BETANCUR-ANCONA ${ }^{1}$, Mukthar SANDOVAL-PERAZA², Aldo ARIAS-TRINIDAD ${ }^{1}$, \\ Santiago GALLEGOS-TINTORE ${ }^{1}$, Eduardo CASTAÑEDA-PÉREZ ${ }^{1}$, Luis CHEL-GUERRERO ${ }^{1}$ (iD
}

\begin{abstract}
Effect of peptides obtained from Phaseolus lunatus L. where biological properties such as antioxidant activity have been found. In addition to improve this beneficial effect, the microencapsulation could be a way to protect the peptides against the environment to which they are exposed. Gums extracted from plant seeds are a potential option such as Guazuma ulmifolia, and its seeds gum exhibits promising properties as coating materials in encapsulation. Two peptide fractions from $P$. lunatus $\mathrm{L}$. were encapsulated ( $>10$ and $<10 \mathrm{kDa}$ ) by ionic gelation using mixtures of $\mathrm{G}$. ulmifolia gum and sodium alginate (GUG:SA). A $2^{3}$ experimental design was used: GUG:SA ratios (A) (70:30 or 30:70); $\mathrm{CaCl}_{2}$ concentrations (B) (0.05 or 0.15 M); and hardening time (C). (10 or $30 \mathrm{~min})$. Multiple variable response analysis with a desirability coefficient identified optimum conditions for each peptide fraction. Better results were obtained for $>10 \mathrm{kDa}$ peptide fraction at optimal conditions of A: 70:30, B: 0.05 and C: 10, obtaining irregular beads with a diameter of $5.85 \mathrm{~mm}^{2}$, Bead Encapsulation efficiency $42 \%$ and 31 and $42 \mathrm{mM}$ TEAC for ABTS and DPPH respectively. These results shown that GUG:SA mixture is a viable encapsulation system for preserving antioxidant peptide fractions.
\end{abstract}

Keywords: encapsulation; ionic gelation; alternative gum; bioactive properties; hydrolysates.

Practical Application: Preserve the antioxidant activity of peptide fractions by encapsulation using mixed gums as wall materials.

\section{Introduction}

Lima bean (Phaseolus lunatus L.) like all beans, is a rich source of proteins, carbohydrates, iron, calcium, and fiber, and has notably low-fat content (Yellavila et al., 2015). When the lima bean protein undergoes an extensive hydrolysis $(>10 \%)$ with sequential enzymatic systems with pepsin-pancreatin it has been obtained peptides with antioxidant activity (Polanco-Lugo et al., 2014; Sandoval-Peraza et al., 2014). One inconvenient in the oral administration of hydrolysates and peptides is their sensitivity to the gastric acid and their vulnerability to gastrointestinal enzymes (Bajpai \& Sharma, 2004), if the peptide could be protected to permeate epithelial barriers in particular the intestinal after the oral consumption and later, the membrane of the target cell, tremendous therapeutic advantage would result (Lundquist \& Artursson, 2016). The use of alginate in the production of beads is one of the most used materials for encapsulation of cells, flavors, probiotics, enzymes, among others., this is an advantage because this material is a non-toxic compound, has biocompatibility and has thermal and chemical stability (Stojanovic et al., 2012).

Guazuma ulmifolia, is a tree species native to the state of Yucatán, México. It has multifold uses ranging from wood, to shade, fodder, and medicinal properties (Manríquez et al., 2011). Limited data are available on the chemical composition of its leaves, bark, roots, and fruit. Some data has been published on the chemical composition of gum from its seeds, showing it to contain mainly galactose and mannose with varying concentrations of glucose and glucuronic and galacturonic acids, depending on seed maturity (Arias-Trinidad et al., 2018; Sandoval-Peraza et al., 2019). No studies exist to date on the physicochemical profile of gum extracted from G. ulmifolia seeds nor on its suitability as an encapsulation material. The objective of the present study was to evaluate different blends of native G. ulmifolia gum with sodium alginate (GUG/SA) in the formation of protective beads on two P. lunatus peptide fractions $(>10$ and $<10 \mathrm{kDa}$ ), finally in vitro gastrointestinal digestion was carried out and the residual antioxidant activity of the encapsulated fractions was determinate.

\section{Materials and methods}

G. ulmifolia fruits were collected from several parks in the city of Mérida, México. P. lunatus seeds were purchased in a local market in Umán, México. Reagents for enzymatic hydrolysis, amino acid and antioxidant activity were purchased from Sigma-Aldrich, other reagents were analytical grade and purchased from Meyer Inc.

\subsection{Extraction of G. ulmifolia gum (GUG)}

The collected fruit were dried in a convection oven at $50^{\circ} \mathrm{C}$ for $6 \mathrm{~h}$, and crushed in a jaw mill (SOILTEST, series 01287, Texas, USA). The dried fruit was placed in a digital sieve shaker (RO-TAP, model E, Lewis Center, Ohio, USA) with 10, 30 and 
100 mesh sieves for 6 min to separate the seeds from the husk residues. The gum extraction was done according with SandovalPeraza et al. (2019), seed:distilled water (1:15 w:v) suspension was prepared and heated at $70^{\circ} \mathrm{C}$ under agitation $(400 \mathrm{rpm}$ with a Caframo RZ-1, Wiarton, Canada) for $4 \mathrm{~h}$. The hydrated seeds were filtered through nylon mosquito screen $(0.5 \mathrm{~mm}$ mesh) and the filtered liquid (hydrated gum) was collected in a container. The seeds were resuspended in distilled water at $1: 5$ (p:v) ratio then agitated and filtered under the same conditions above mentioned. The suspensions were joined and precipitated with ethanol (95\%) in a 1:5 (v:v) ratio, this mixture were filtered through $100(149 \mu \mathrm{m})$ and $200(74 \mu \mathrm{m})$ mesh screen and then the gum obtained was dried overnight at $60{ }^{\circ} \mathrm{C}$ (Imperial V lab-line model $3476 \mathrm{M}$, Boston, USA).

\subsection{P. lunatus flour and protein concentrate (PC)}

The $P$. lunatus seeds were cleaned and crushed in a roller mill (Cemotec 1990, Tecator, Sweden). The resulting flour was passed through a 200-mesh screen. Using the flour, a protein concentrate $(\mathrm{PC})$ was obtained by alkaline solubilization $(\mathrm{pH}$ 10 with $\mathrm{NaOH} 1 \mathrm{~N}$ ) and isoelectric precipitation of protein (Betancur-Ancona et al., 2004).

\subsection{Proximal composition of GUG and PC}

The Association of Official Analytical Chemists (2005) methods were used to measure the nitrogen (Method 954.01), fat (920.39), ash (923.03), fiber (962.09), and moisture (925.09) contents of the GUG and P. lunatus PC. Protein was calculated as nitrogen content using the factor 6.25 , and carbohydrate content was estimated as nitrogen-free extract (NFE).

\subsection{Enzymatic hydrolysis of PC}

The P. lunatus PC was enzymatically hydrolyzed using a sequential pepsin-pancreatin system with total reaction time of $90 \mathrm{~min}$, based on the methodology of Chel-Guerrero et al.
(2012). Degree of hydrolysis (DH) of the resulting protein hydrolysate $(\mathrm{PH})$ was quantified following the technique of Nielsen et al. (2001).

\subsection{Ultrafiltration of the protein hydrolysate (PH)}

The ultrafiltration was done following Cho et al. (2004). Two peptide fractions (PFs) were obtained using an ultrafiltration system (Millipore 106844304 Model M2000, Massachusetts, USA) with ultrafiltration membranes (Millipore ${ }^{\circledR} 2000$ ), they were identified as the $>10 \mathrm{kDa} P F$ and $<10 \mathrm{kDa}$ PF. Protein content in each PF was measured following Lowry et al. (1951).

\subsection{Peptide fraction amino acid profiles}

The amino acid composition of each PF was measured using the method of Alaiz et al. (1992). Amino acids were separated using high-performance liquid chromatography (HPLC) with an automatic injection HPLC (Agilent Series 1100) and a Nova Pack $\mathrm{C}_{18} 4 \mu \mathrm{m}$ reverse phase column ( $300 \times 3.9 \mathrm{~mm}$; Waters). Tryptophan was determined according Yust et al. (2003).

\subsection{Peptide fraction encapsulation}

The evaluation of GUG:SA as an encapsulation material of the $P$. lunatus $P F s$ by ionic gelation was done with a $2^{3}$ factorial experimental design with four central treatments (9-12) for each PF (Table 1). Each assay included a blank treatment (BT) without PFs; and a control (CtT) consisted of PFs in only SA gum by under central conditions. Three factors were employed: factor A, two GUG:SA gum proportions (30:70 and 70:30 [w/w]); factor B, two $\mathrm{CaCl}_{2}$ concentrations $(0.05$ and $0.15 \mathrm{M})$; and factor $\mathrm{C}$, two hardening times (10 and $30 \mathrm{~min}$ ). Central treatment conditions were the intermediate values of the above factors. The response variables used were bead encapsulation efficiency (BEE); protein release and residual antioxidant activity (AA) in a gastrointestinal simulated system. One $g$ of each blend of GUG:SA (Table 1) was dispersed in $100 \mathrm{~mL}$ distilled water in a vessel $(250 \mathrm{~mL}$ beaker $)$

Table 1. Bead encapsulation efficiency, protein release and residual antioxidant activity of capsules containing $>10 \mathrm{kDa}$ and $<10 \mathrm{kDa}$ of $P$. lunatus $\mathrm{PF}$.

\begin{tabular}{|c|c|c|c|c|c|c|c|c|c|c|c|c|c|c|c|c|c|}
\hline \multirow{3}{*}{$\mathrm{T}$} & \multirow{3}{*}{ A } & \multirow{3}{*}{ B } & \multirow{3}{*}{ C } & \multirow{2}{*}{\multicolumn{2}{|c|}{ BEE (\%) }} & \multicolumn{4}{|c|}{$\begin{array}{l}\text { Protein release } \\
(\mathrm{mg})\end{array}$} & \multicolumn{4}{|c|}{ ABTS mM equivalent of Trolox } & \multicolumn{4}{|c|}{$\begin{array}{c}\text { DPPH mM equivalent of } \\
\text { Trolox }\end{array}$} \\
\hline & & & & & & \multicolumn{2}{|c|}{$>10 \mathrm{kDa}$} & \multicolumn{2}{|c|}{$<10 \mathrm{kDa}$} & \multicolumn{2}{|c|}{$>10 \mathrm{kDa}$} & \multicolumn{2}{|c|}{$<10 \mathrm{kDa}$} & \multicolumn{2}{|c|}{$>10 \mathrm{kDa}$} & \multicolumn{2}{|c|}{$<10 \mathrm{kDa}$} \\
\hline & & & & $\begin{array}{l}>10 \\
\mathrm{kDa}\end{array}$ & $\begin{array}{l}<10 \\
\mathrm{kDa}\end{array}$ & GS & IS & GS & IS & GS & IS & GS & IS & GS & IS & GS & IS \\
\hline 1 & + & - & + & $37^{\mathrm{b}}$ & $16^{\mathrm{b}}$ & $55^{\mathrm{d}}$ & $129^{c}$ & $63^{\mathrm{d}}$ & $14^{\mathrm{h}}$ & $81^{\mathrm{f}}$ & $15^{\mathrm{h}}$ & $107^{\mathrm{d}}$ & $341^{\mathrm{a}}$ & $38^{g}$ & $11^{\mathrm{g}}$ & $18^{\mathrm{h}}$ & $52^{\mathrm{d}}$ \\
\hline 2 & + & - & - & $42^{\mathrm{a}}$ & $17^{\mathrm{a}}$ & $76^{c}$ & $134^{\mathrm{b}}$ & $93^{\mathrm{b}}$ & $77^{\mathrm{b}}$ & $92^{\mathrm{e}}$ & $31^{\mathrm{g}}$ & $142^{\mathrm{a}}$ & $110^{\mathrm{d}}$ & $0^{\mathrm{i}}$ & $42^{\mathrm{d}}$ & $136^{\mathrm{b}}$ & $21^{\mathrm{f}}$ \\
\hline 3 & + & + & + & $30^{c}$ & $17^{\mathrm{a}}$ & $103^{a}$ & $48^{\mathrm{f}}$ & $102^{\mathrm{a}}$ & $71^{c}$ & $46^{\mathrm{h}}$ & $29^{\mathrm{f}}$ & $63^{e}$ & $123^{\mathrm{b}}$ & $120^{\mathrm{e}}$ & $17^{\mathrm{f}}$ & $14^{\mathrm{i}}$ & $16^{\mathrm{g}}$ \\
\hline 4 & + & + & - & $38^{\mathrm{b}}$ & $15^{\mathrm{c}}$ & $51^{\mathrm{e}}$ & $138^{\mathrm{a}}$ & $83^{c}$ & $68^{\mathrm{d}}$ & $51^{g}$ & $9^{i}$ & $121^{\mathrm{b}}$ & $112^{c}$ & $33^{\mathrm{h}}$ & $93^{\mathrm{a}}$ & $116^{\mathrm{e}}$ & $2^{\mathrm{h}}$ \\
\hline 5 & - & - & + & $11^{\mathrm{g}}$ & $8^{\mathrm{d}}$ & $17^{\mathrm{h}}$ & $38^{\mathrm{g}}$ & $39^{\mathrm{h}}$ & $40^{\mathrm{g}}$ & $665^{a}$ & $185^{\mathrm{a}}$ & $119^{c}$ & $73^{\mathrm{e}}$ & $128^{\mathrm{d}}$ & $28^{\mathrm{e}}$ & $125^{\mathrm{c}}$ & $2^{\mathrm{h}}$ \\
\hline 6 & - & - & - & $19^{\mathrm{d}}$ & $10^{c}$ & $37^{\mathrm{f}}$ & $60^{\mathrm{e}}$ & $45^{\mathrm{f}}$ & $57^{\mathrm{e}}$ & $142^{\mathrm{d}}$ & $112^{\mathrm{b}}$ & $55^{\mathrm{g}}$ & $31^{g}$ & $103^{\mathrm{f}}$ & $28^{\mathrm{e}}$ & $98^{\mathrm{f}}$ & $118^{\mathrm{c}}$ \\
\hline 7 & - & + & + & $16^{\mathrm{e}}$ & $8^{\mathrm{d}}$ & $18^{\mathrm{h}}$ & $60^{\mathrm{e}}$ & $39^{\mathrm{h}}$ & $45^{\mathrm{f}}$ & $514^{\mathrm{b}}$ & $52^{\mathrm{e}}$ & $57^{\mathrm{f}}$ & $9^{\mathrm{h}}$ & $159^{a}$ & $29^{e}$ & $88^{g}$ & $138^{\mathrm{a}}$ \\
\hline 8 & - & + & - & $18^{\mathrm{d}}$ & $16^{\mathrm{b}}$ & $24^{\mathrm{g}}$ & $68^{\mathrm{d}}$ & $41^{\mathrm{g}}$ & $117^{\mathrm{a}}$ & $241^{c}$ & $73^{\mathrm{d}}$ & $52^{\mathrm{h}}$ & $9^{\mathrm{h}}$ & $150^{\mathrm{b}}$ & $55^{\mathrm{b}}$ & $196^{\mathrm{a}}$ & $136^{\mathrm{b}}$ \\
\hline $9-12$ & 0 & 0 & 0 & $44^{\mathrm{a}}$ & $7^{e}$ & $88^{\mathrm{b}}$ & $132^{\mathrm{b}}$ & $55^{\mathrm{e}}$ & $17^{\mathrm{i}}$ & $7^{\mathrm{i}}$ & $103^{c}$ & $6^{\mathrm{i}}$ & $34^{\mathrm{f}}$ & $135^{c}$ & $53^{c}$ & $122^{\mathrm{d}}$ & $39^{\mathrm{e}}$ \\
\hline $\mathrm{CtT}$ & 0 & 0 & 0 & 60 & 28 & 410 & 94 & 142 & 140 & 29 & 281 & 13 & 262 & 121 & 58 & 140 & 109 \\
\hline
\end{tabular}

T: treatment; factors: A: GUG/SA ratio [(+) 70:30], [(0) 50:50], [(-) 30:70]; B: $\mathrm{CaCl}_{2}$ concentration [(+) 0.15], [(0) 0.1], [(-) 0.05]; C: hardening time [(+) 30], [(0) 20], [(-) 10]; central treatment (9-12); CtT: control treatment with only sodium alginate; BEE: bead encapsulation efficiency; GS: gastric system; and IS: intestinal system. Different superscript letters in the same column indicate significant difference $(\mathrm{P}<0.05)$. 
while stirring at $60{ }^{\circ} \mathrm{C}$ for $30 \mathrm{~min}$ at $650 \mathrm{rpm}$ using a magnetic stirrer, $2 \mathrm{~g}$ of $\mathrm{PF}$ was added and homogenized at 10,000 rpm (T18 Digital Ultra-Turrax ${ }^{\oplus}$, IKA-Labortechnik, Staufen, Germany). The solution was passed through a peristaltic pump (ColePalmer, Model 7553-70, Barrington, USA) and added as drops from a $10 \mathrm{~cm}$ height to $100 \mathrm{~mL} \mathrm{CaCl}$, solution under constant agitation. The beads were recovered by decantation, washed with deionized water, and lyophilized at $-47^{\circ} \mathrm{C}$ and $13 \times 10^{-3} \mathrm{mbar}$. An additional control treatment (TT) was prepared using only SA under central treatment conditions.

\subsection{Capsule diameter and morphology}

Five beads were randomly selected to evaluate morphology and area. Morphology was visualized with a stereoscopic microscope (5x, MOTIC SMZ-168, Richmond, Canada), images were taken with a $10 \mathrm{MP}$ camera and processed with the Motic Images Manager software (V. Plus 2.0). The bead area (BAr) of the capsules for each treatment was measured with the program ImageJ 1.47 .

\subsection{Bead encapsulation efficiency (BEE)}

BEE (\%) was calculated according to the method of Ishii \& Nagasaka (2001) using Equation 1.

$$
E E(\%)=\left[\frac{(C b-C a)}{C b}\right] \times 100
$$

Where $\mathrm{Cb}$ is the amount of protein used for gum bead preparation $(2 \mathrm{~g})$ and $\mathrm{Ca}$ is the amount of protein in the whole bead after formation. Protein was quantified following the technique of Lowry et al. (1951).

\subsection{In vitro gastrointestinal release study}

In vitro release capacity of the beads was evaluated with an adapted version of the method of Takagi et al. (2003). Dry beads $(100 \mathrm{mg}$ ) for each treatment (separately), were placed in a $50 \mathrm{~mL}$ beaker containing $25 \mathrm{~mL}$ of $\mathrm{NaCl}(2 \mathrm{mg} / \mathrm{mL})$ at $\mathrm{pH} 2$ (adjusted with $\mathrm{HCl} 2 \mathrm{~N}$ ). The mixture was shaken with a multi-position magnetic stirrer (Variomag Poly 15, Illinois, USA) at $350 \mathrm{rpm}$ for $2 \mathrm{~h}$ at $37^{\circ} \mathrm{C}$ to simulate gastric (GS) conditions. The beads were recovered by decanting the GS, placed in a beaker containing $25 \mathrm{~mL} 0.25 \mathrm{M}$ phosphate buffer at $\mathrm{pH} 6.8$, and shaken at $1.5 \mathrm{rpm}$ for $3 \mathrm{~h}$ at $37^{\circ} \mathrm{C}$ to simulate intestinal system (IS) conditions. Again, the beads were recovered by decanting the IS. The solutions decanted in the GS and IS simulations of each sample were stored in $50 \mathrm{~mL}$ conical centrifuge tubes for subsequent evaluation of released protein content and residual antioxidant capacity.

\subsection{Antioxidant activity by $\mathrm{ABTS}^{\bullet+}$ radical scavenging assay}

The ABTS decolorization assay was done according with Pukalskas et al. (2002). The antioxidant activity in the samples was quantified by mixing $10 \mu \mathrm{L}$ from PFs, GS or IS aliquots and $990 \mu \mathrm{L}$ of ABTS radical cation and measuring absorbance at $734 \mathrm{~nm}$ after $6 \mathrm{~min}$.

\subsection{Antioxidant activity by 2,1-diphenyl-1-picrylhydrazyl (DPPH) radical scavenging}

The DPPH radical method was also quantified according with Xia et al. (2012). A $10 \mu \mathrm{L}$ sample from PFs, GS or IS added to $990 \mu \mathrm{L} 0.1 \mathrm{mM}$ DPPH in ethanol, after $30 \mathrm{~min}$ in darkness the sample absorbance was recorded at $516 \mathrm{~nm}$ in a UV/Vis spectrophotometer (PerkinElmer, Colorado, USA).

\subsection{Statistical analysis}

The results were processed using descriptive statistics with central tendency and dispersion measurements. An analysis of variance and regression were run for each experiment, corresponding to the $2^{3}$ factorial design, to identify differences within each response variable and their best conditions. Later, optimum encapsulation process conditions were identified using a multiple responses analysis with a desirability test. All analyses were run following Montgomery (2017) and using the Statgraphics Centurion version 19 software (Statgraphics Technologies, INC., Virginia, EUA).

\section{Results and discussion}

Proximal composition of the GUG was $81.64 \%$ NFE, $10.41 \%$ ash, $0.10 \%$ crude fiber, $7.05 \%$ protein, and $0.8 \%$ fat. The PC had a protein content of $62.37 \%$ (d.b.) and $25.38 \%$ of DH consequent upon sequential hydrolysis. This value was higher than the $15.97 \%$ DH reported by Polanco-Lugo et al. (2014) and lower than the $32.16 \%$ reported by Chel-Guerrero et al. (2012) in P. lunatus. These authors used the same sequential enzymatic system but with a different enzyme-substrate ratio (1:50 and 1:10 w/w respectively). Notwithstanding the differences, the $\mathrm{DH}$ obtained in this study would provide peptides with adequate antioxidant capacity (Polanco-Lugo et al., 2014; Sandoval-Peraza et al., 2014).

After the PFs obtention, the protein content and antioxidant values of Trolox Equivalent Antioxidant Capacity (TEAC) of $\mathrm{ABTS}^{\bullet+}$ and $\mathrm{DPPH}$ values in the $>10 \mathrm{kDa}$ PF were $0.6138 \mathrm{mg}$ protein $/ \mathrm{mL}, 17.07 \mathrm{mM} / \mathrm{mg}$ protein and $0.844 \mathrm{mM} / \mathrm{mg}$ protein (respectively), and the GUG antioxidant capacity was not detectable. In the case of the $\mathrm{PF}<10 \mathrm{kDa}$ the values for the same parameters were $0.5736 \mathrm{mg}$ protein $/ \mathrm{mL}, 22.72 \mathrm{mM} / \mathrm{mg}$ protein of TEAC and $3.55 \mathrm{mM} / \mathrm{mg}$ protein of DPPH activity. Sandoval-Peraza et al. (2014) reported a similar values of antioxidant activity in a $\mathrm{PF}<10 \mathrm{kDa}(26.94 \mathrm{mM}$ of TEAC/mg protein) from $P$. lunatus.

Table 1 show the values of BEE, protein released in gastric system (GS) and intestinal system (IS), and TEAC of ABTS ${ }^{\bullet+}$ and DPPH of the PFs encapsulated. The BEE of the $>10 \mathrm{kDa}$ $\mathrm{PF}$ was in a range of $11-44 \%$. After in vitro digestion it was observed that all treatments had a good retention of the PF in the GS and a total liberation of the PF in IS, all treatments shown TEAC of ABTS $^{\bullet+}$ and DPPH. In the case of the $<10 \mathrm{kDa}$ PF it was observed a range of BEE between $7-17 \%$, all treatments 
had protein release in GS and IS systems and the peptides encapsulated shown antioxidant activity.

A desirability (D) score was calculated for all responses and each one weighted based on its assigned importance (Montgomery, 2017). This allowed more accurate selection of the responses to be maximized and minimized, such as residual AA in the IS and GS. All responses were assigned a weight value of 1 , and an impact value (1 to 5 interval) based on response variable effect. These values were combined to calculate the composite desirability and a compound D score of 1 is optimal (de la Vara Salazar \& Gutiérrez Pulido, 2008). An optimization plot was used to adjust variable settings and determine how the changes affected the response. Based on their $0.54 \mathrm{D}$ score, the best encapsulation conditions for the $>10 \mathrm{kDa}$ PF were 70:30 GUG:SA, $0.05 \mathrm{M} \mathrm{CaCl}_{2}$ concentration and 10 min hardening time (Treatment 2, Table 2).

The highest $\mathrm{D}$ score for the $<10 \mathrm{kDa}$ PF was 0.36 , corresponding to $30: 70 \mathrm{GUG}: \mathrm{SA}, 0.05 \mathrm{M} \mathrm{CaCl}_{2}$ concentration and $10 \mathrm{~min}$ hardening time (Treatment 6, Table 2). However, predictive calculations showed that optimal conditions for the $>10 \mathrm{kDa}$ PF were 63:37 GUG:SA, $0.1 \mathrm{M} \mathrm{CaCl}_{\text {concentration and } 10 \mathrm{~min}}$ hardening time, which would raise the $\mathrm{D}$ score to 0.56 therefore it can be assumed that treatment 2 is closer to optimal conditions. For the $<10 \mathrm{kDa}$ PF optimum conditions corresponded very near to the CtT conditions (50:50 GUG:SA, $0.1 \mathrm{M} \mathrm{CaCl}_{2}$ concentration and $20 \mathrm{~min}$ hardening time), which would result in a $0.45 \mathrm{D}$ score.

The beads morphology obtained after the encapsulation process for PFs are shown in the Tables 3 and 4 . All the treatments exhibited an irregular polyhedral morphology with angular edges in both forms, the alginate beads being the ones with the smallest area. The same irregular forms behavior was reported in beads formed by cross-linking technique with blends of carboxymethylated flamboyant gum and SA (SandovalPeraza et al., 2014) and GUG:SA (Sandoval-Peraza et al., 2019).

After the lyophilization process, the treatments with the highest GUG concentration exhibited structural cracks and a

Table 2. Multiple response variables optimization of encapsulated peptide fractions of $P$. lunatus.
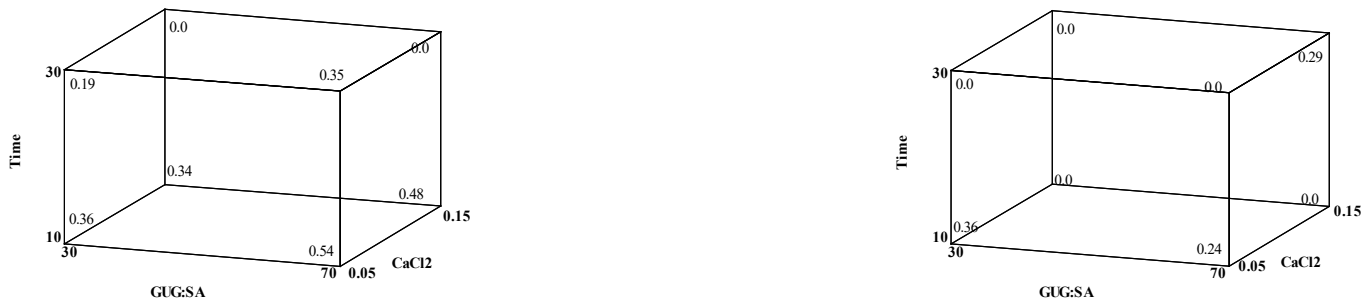

Factors: GUG:SA ratio (only GUG value shown); $\mathrm{CaCl}_{2}$ concentration (M); hardening time (min). Factor values are expressed in real units.

Table 3. Morphology of wet and dry beads with the $>10 \mathrm{kDa}$ P. lunatus peptide fraction.

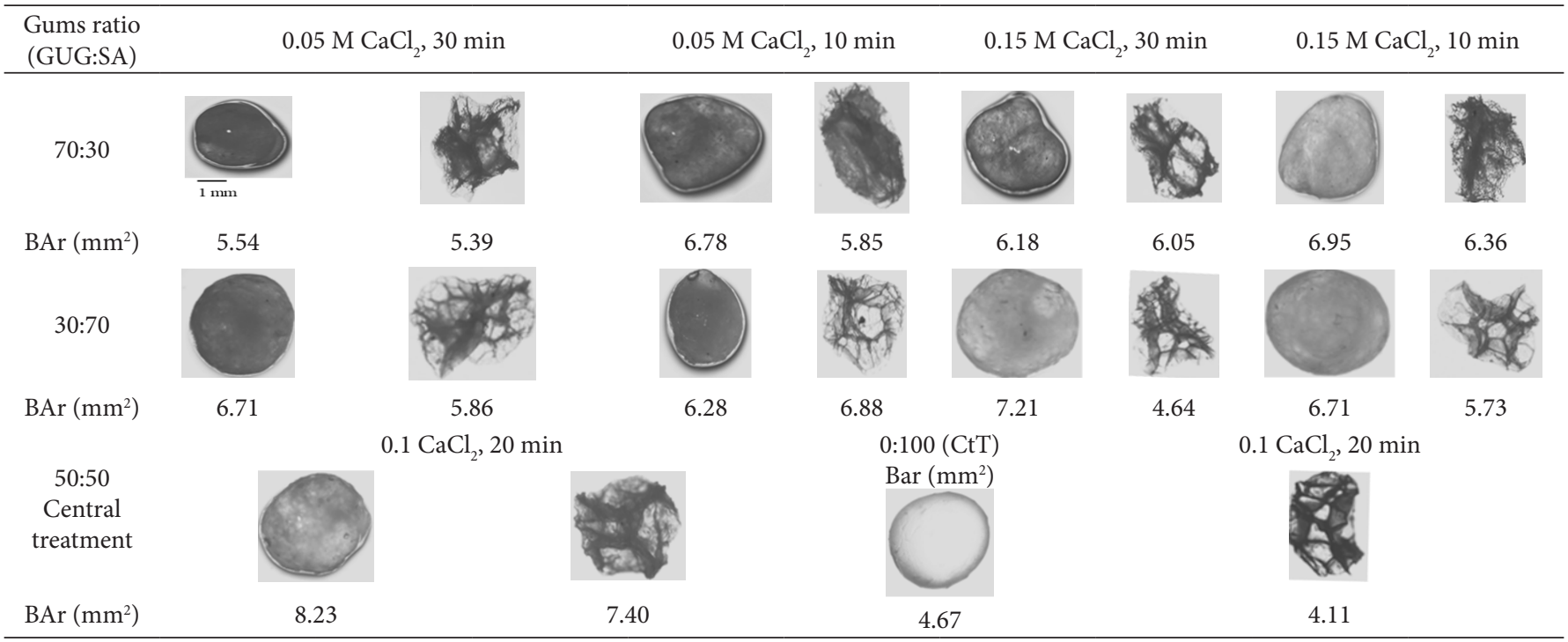


Table 4. Morphology of wet and dry beads with the $<10 \mathrm{kDa}$ P. lunatus peptide fraction.

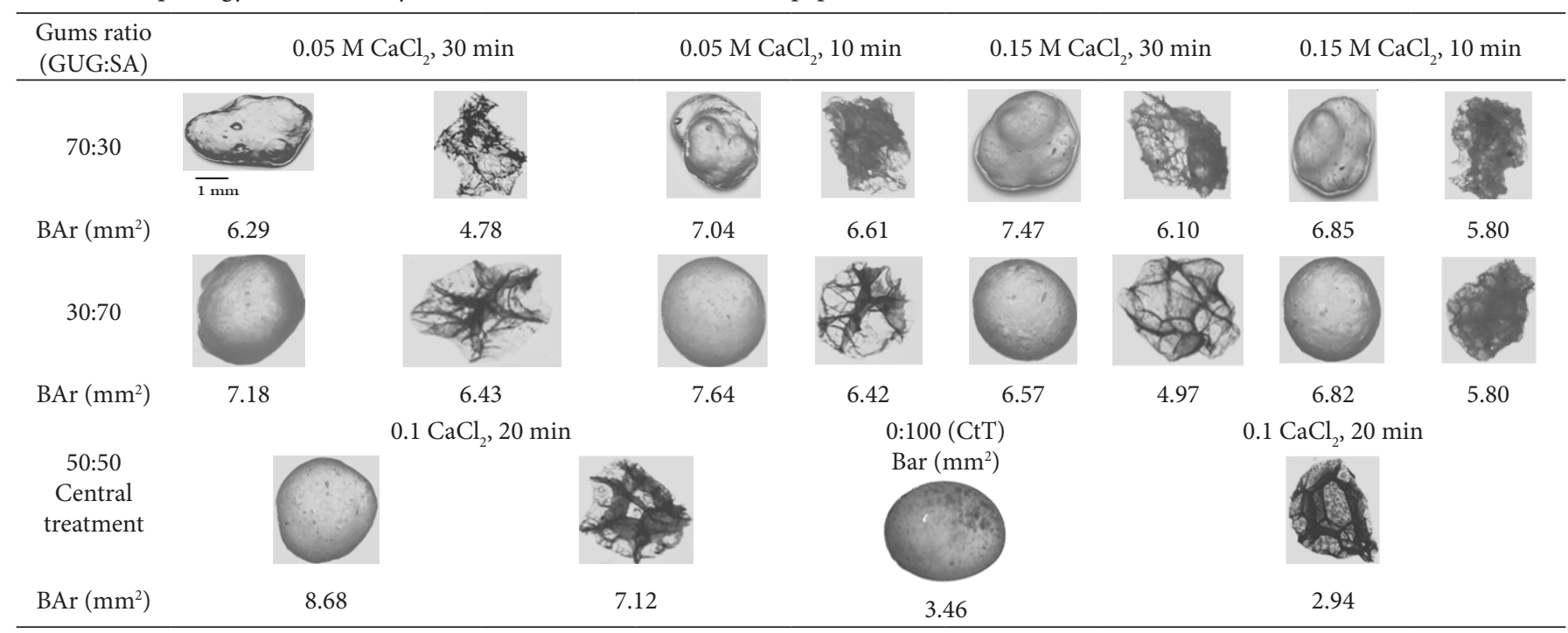

Table 5. Amino acid (AA) profile of $P$. lunatus peptide fractions ( $>10$ and $<10 \mathrm{kDa}$ ).

\begin{tabular}{|c|c|c|c|c|c|c|c|c|}
\hline \multirow{2}{*}{ AA } & \multicolumn{8}{|c|}{ Content (g/100 g of protein) } \\
\hline & $>10 \mathrm{kDa}$ & $<10 \mathrm{kDa}$ & AA & $>10 \mathrm{kDa}$ & $<10 \mathrm{kDa}$ & AA & $>10 \mathrm{kDa}$ & $<10 \mathrm{kDa}$ \\
\hline Asx & $11.52 \pm 0.10$ & $10.98 \pm 0.05$ & Ala & $3.16 \pm 0.06$ & $4.22 \pm 0.13$ & Leu & $6.12 \pm 0.07$ & $6.87 \pm 0.06$ \\
\hline Glx & $12.67 \pm 0.09$ & $11.54 \pm 0.10$ & Pro & $8.56 \pm 0.05$ & $9.37 \pm 0.10$ & Phe & $4.91 \pm 0.09$ & $4.80 \pm 0.10$ \\
\hline His & $3.27 \pm 0.08$ & $2.99 \pm 0.12$ & Val & $4.27 \pm 0.05$ & $5.75 \pm 0.09$ & $\operatorname{Trp}$ & $2.57 \pm 0.07$ & $1.18 \pm 0.10$ \\
\hline Gly & $4.12 \pm 0.13$ & $3.32 \pm 0.09$ & Met & $0.43 \pm 0.07$ & $0.77 \pm 0.08$ & & & \\
\hline Arg & $>10 \mathrm{kDa}$ & $<10 \mathrm{kDa}$ & & $>10 \mathrm{kDa}$ & $<10 \mathrm{kDa}$ & & $>10 \mathrm{kDa}$ & $<10 \mathrm{kDa}$ \\
\hline AAA & 17.89 & 16.66 & $\operatorname{ArA}$ & 20.07 & 20.48 & HbA & 39.40 & 42.67 \\
\hline HрА & 44.55 & 42.58 & & & & & & \\
\hline
\end{tabular}

Antioxidant amino acids (AAA): Trp, Met, His, Tyr, Lys; aromatic amino acids (ArA): Pro, Phe, Tyr, Trp; hydrophobic amino acids (HbA): Ala, Val, Ile, Leu, Tyr, Phe, Trp, Pro, Met; hydrophilic amino acids (HpA): Arg, Lys, Asx, Glx, His.

rough texture. Lyophilization of capsules produces size variability, structural fragility and high porosity, characteristics that influence active substance stability (Chan et al., 2011). This effect could be explained by the long processing time and formation of ice crystals in the lyophilization process that can affect peptide structure (Sarabandi et al., 2020).

Although the shapes of the beads were irregular but the blends of GUG:SA could be an advantage, because it has been reported that the capsules containing only alginate, cross-linked with calcium may not be sufficient to give a better encapsulation of the material (Jaya et al., 2009). The addition of GUG in the formation of beads could produce a certain type of dense membrane to have a better control of the release rate of the protein (Yeo et al., 2001).

According to $\mathrm{D}$ score, the treatments 2 and 6 had the best $\mathrm{BEE}$ for the $>10 \mathrm{kDa} P F(42 \%)$ and $<10 \mathrm{kDa} \mathrm{PF}(10 \%)$. The differences between BEE depends on many factors, for example, the kind of gum used, the size of material encapsulated and the concentration of the calcium concentration. Sandoval-Peraza et al. (2019) reported that the use of the GUG in the encapsulation of low weight peptide fractions is infeasible because there is no control over the retention of the peptide fraction. This behavior was observed in the lower values of BEE in the $<10 \mathrm{kDa} P F$ (treatment 6). On the other hand, it was observed that the use of the GUG in the encapsulation of the $>10 \mathrm{kDa}$ PF has a better BEE value that are comparable with the values reported by Sandoval-Peraza et al. (2014) by the encapsulation of peptides from $P$. lunatus with blends of carboxymethylated flamboyant gum and sodium alginate which were in a range of $31.49-36.27 \%$.

As a possible explanation of the different BEE for the PFs could be the charge activity on the polypeptide chains since, this PFs probably stablish interaction with the polysaccharides through electrostatic interactions as cite Dickinson (2009), and as they have approximately the same amount of charged amino acids (Table 5), this interaction was dependent on the size of the chains In addition, the protein in the GUG (7.07\%) may have generated a better interaction with the positive charge of some amino acids. A similar effect, but with a lower BEE (15 to 17\%) was observed in the $<10 \mathrm{kDa} P F$ capsules in the $70: 30$ ratio 
(Table 1), apparently in this case the process was governed more by polypeptide size and composition than the presence of SA. This was clear since in both experiments the highest BEE was in the CtT: $60 \%$ in the $>10 \mathrm{kDa} P F$ and $28 \%$ in the $<10 \mathrm{kDa} P F$.

Based on PF amino acid composition, about the hydrophilic ones are $44.6 \%$ in the $>10 \mathrm{kDa} P F$ and $42.6 \%$ in the $<10 \mathrm{kDa} P F$ (Table 5), which limits their retention since they tend to interact with an aqueous medium. This phenomena is linked to the fact that peptide fractions contain a high amount of acidic amino acids, from 22 to $24 \%$, and that repulsion between the charges of the uronic acids in the SA, under encapsulation conditions (and probably also in the GUG), depending on the $\mathrm{pH}$, constitute a mechanism of instability (Bayer et al., 2011).

With regard to the $\mathrm{PF}$ of $>10 \mathrm{kDa}$, protein release analysis indicated that Treatment 2 had a release of $134 \mathrm{mg}$ of protein in the IS and a lower release in the GS. This is the desired behavior since peptides are known to exert bioactivity in the IS (SeguraCampos et al., 2011). Another factor to take into account is the improvement in the PF released in IS using blends of GUG:SA in comparison with the $\mathrm{CtT}$ which had an uncontrolled release of the PF in GS. Jaya el al. (2009) reported the effect of alginatepectin blends composition on drug release characteristics, and proposed that it is possible to get a different bioactive material release pattern by varying the composition of the polysaccharides blends. The same effect was reported by Sandoval-Peraza et al. (2014) where it was observed that the use of gum blends improves the retention of the PF in comparison with the capsules formed only with alginate. Protein release in the $<10 \mathrm{kDa} P F$ in both the IS and GS was lower than the quantities in the $>10 \mathrm{kDa} P F$, but as aforementioned, the GUG does not have the ability to retain PF with low molecular weight.

These results may be associated with the higher amounts of SA, since the carboxyl groups of glutamic and aspartic acids, or those of lysine, arginine, and histidine, can attract or repel each other depending on medium $\mathrm{pH}$. A higher quantity of SA, its chemical composition, the core material and an acid medium (Silva et al., 2014) gradually erode the capsule, allowing the PF to diffuse into the aqueous medium (Rodríguez et al., 2017). Capsule porosity generated by the drying method used (lyophilization) formed crystals and thus allowed more contact between the gastric medium and the encapsulated peptides (Kang et al., 1999).

Hydrophilic amino acids ( $\mathrm{HpA}$ ) were the main amino acids in both PF, followed by hydrophobic amino acids (HbA) and finally the aromatics (ArA) (Table 5). The relative proportions of amino acid types are important because they can influence PF properties. For example, the $\mathrm{HbA}$ are known to have a structure and lipid solubility that allow the neutralization of hydroxyl groups, free radicals and the lipoperoxidation chain reaction (Bauchart-Thevret et al., 2009; Ajibola et al., 2011). The amino acid His, and the ArA Tyr and Trp, can donate protons to electron-deficient radicals to stabilize them, while maintaining stability through resonance structures (Intiquilla et al., 2016). Despite similarities in total ArA content in the two PF, the $>10 \mathrm{kDa}$ PF had lower amounts of HbA than the $<10 \mathrm{kDa}$ PF. In contrast, the $\mathrm{HpA}$ were higher in the $<10 \mathrm{kDa} P F$ than in the $>10 \mathrm{kDa}$ PF. Amino acid composition and microencapsulation factors were involved in protein release and antioxidant activity. For instance, the $>10 \mathrm{kDa}$ PF composition at any of the GUG:SA ratios provided better antioxidant activity as quantified with ABTS (polar and non-polar) and DPPH (non-polar), at least partially in response to environment conditions. Hydrophobic amino acids act as antioxidants by increasing peptide solubility in non-polar environments thereby facilitating better interaction with free radicals, which facilitates measurement of their activities (Kim et al., 2019). Amino acid composition in the $<10 \mathrm{kDa} P F$ did little to improve antioxidant activity since in this case it probably depended more on molecule size.

Under the optimal conditions (Treatment 2) the $>10 \mathrm{kDa}$ $\mathrm{PF}$ had a $42 \% \mathrm{BEE}$, its protein release in the IS was $134 \mathrm{mg}$ and acceptable value of ABTS AA (31 mM Trolox equivalent/mg protein). This is lower than that reported for a $>10 \mathrm{kDa}$ fraction from hard-to-cook common bean (P. vulgaris) non encapsulated (170 mM Trolox equivalent/mg protein AA) (Ruiz-Ruiz et al., 2013) and higher than protein hydrolysates from other legumes with values 14.3 -15.1 mM Trolox equivalent/mg protein (SeguraCampos et al. 2013). In the case of DPPH AA had $42 \mathrm{mM}$ Trolox equivalent. This is notably lower than the 414.11 to $726.98 \mathrm{mM}$ TEAC AA $\left(\mathrm{ABTS}^{\bullet+}\right.$ ) reported for a $<10 \mathrm{kDa}$ P. lunatus PF microencapsulated with Salvia hispanica L. native gum (SandovalPeraza, 2015) using different encapsulating conditions. In the same study protein release in the IS was between 3.8 to $6.9 \mathrm{mg}$ protein, and the GS conditions favored protein release (10.52 to $27.34 \mathrm{mg}$ protein).

Generally, the $<10 \mathrm{kDa}$ PF treatments did not favor BEE or protein release in the IS rather than the GS. Nonetheless, the best treatment selected was 6 (Table 1) that had a good balance on ABTS AA, and DPPH AA residuals in the IS system (31 and $118 \mathrm{mM}$ TEAC respectively), in the latter case higher than the fraction $>10$ in the optimal treatment. As amino acid composition was similar in the two PFs, with higher aromatic (ArA) and antioxidant (AAA) amino acid contents; these amino acids are attributed antioxidant activity due to their ability to donate protons or accept electrons and modify the microenvironment to improve AA (Ajibola et al., 2011). Then, these results demonstrate core size and amino acid composition, and capsule wall chemical composition were the most important factors influencing bioactivity. This comprehensive evaluation showed that the presence of GUG improved microcapsule formation and promoted antioxidant capacity under intestinal conditions in vitro. Degree of hydrolysis is important factor to consider when deciding which materials are best for use in microcapsule walls and as a filling agent. These can modify the environment of the bioactive agent through their hydrophobic characteristics or loading potential (Sarabandi et al., 2019; Sarabandi et al., 2020).

\section{Conclusion}

The best conditions established for the encapsulation of peptide fractions (PF) of different molecular size were 70:30 GUG: SA ratio (Factor A), $0.05 \mathrm{M} \mathrm{CaCl} 2$ (Factor B) and 10 min hardening time (Factor $\mathrm{C}$ ) for the $\mathrm{FP}>10 \mathrm{kDa}$ and at $30: 70,0.05 \mathrm{M}$ and $10 \mathrm{~min}$ respectively for $\mathrm{FP}<10 \mathrm{kDa}$. Optimal conditions, according to the desirability coefficient, were nearly 
the same conditions mentioned for $\mathrm{PF}>10 \mathrm{kDa}$ and in the case of FP $<10 \mathrm{kDa}$ these moved towards the central treatment: 50:50, $0.1 \mathrm{M}$ and $20 \mathrm{~min}$, for factors $\mathrm{A}, \mathrm{B}$ and $\mathrm{C}$ respectively. These optimal conditions yielded particles of $5.85 \mathrm{~mm} 2$ in area, and a residual antioxidant activity in the intestinal system (IS) in vitro of 31 and $42 \mathrm{mM}$ TEAC for ABTS and DPPH respectively. In the case of $\mathrm{PF}>10$ and for $\mathrm{FP}<10 \mathrm{kDa}$, the respective values were $6.42 \mathrm{~mm} 2$ and 34 and $39 \mathrm{mM}$ TEAC, although the amount of protein released in the IS of $\mathrm{FP}>10 \mathrm{kDa}$ was $134 \mathrm{mg}$ against $7 \mathrm{mg}$ for the $\mathrm{FP}<10 \mathrm{kDa}$. This could be adduced to be a function of the capacity of the capsules to retain the large fractions measured as the bead encapsulation efficiency, which was 42 and 7\% respectively. Although the proportion of amino acids identified as antioxidants was similar 17.89 and $16.66 \mathrm{~g} / 100 \mathrm{~g}$ protein, which is reflected in the similar values of antioxidant capacity, the smaller peptide chains in the $\mathrm{FP}<10 \mathrm{kDa}$ were less retained than the larger ones. The mixture of different hydrocolloids used to protect the bioactive peptides allowed them to resist the passage through the gastric environment and its absorption in the intestine to be able to exercise its antioxidant capacity. Formulated beads would be incorporated into foods such as drinks and dairy products.

\section{Acknowledgements}

The research reported here forms part of a $\mathrm{PhD}$ funded by a grant (CVU 385974) from the Consejo Nacional de Ciencia y Tecnología (CONACYT, 2015-2018).

\section{References}

Ajibola, C. F., Fashakin, J. B., Fagbemi, T. N., \& Aluko, R. E. (2011). Effect of peptide size on antioxidant properties of African yam bean seed (Sphenostylis stenocarpa) protein hydrolysate fractions. International Journal of Molecular Sciences, 12(10), 6685-6702. http:// dx.doi.org/10.3390/ijms12106685. PMid:22072912.

Alaiz, M., Navarro, J. L., Girón, J., \& Vioque, E. (1992). Amino acid analysis by high-performance liquid chromatography after derivatization with diethyl ethoxymethylenemalonate. Journal of Chromatography A, 591(1-2), 181-186. http://dx.doi.org/10.1016/0021-9673(92)80236-N. PMid:1613051.

Arias-Trinidad, A., Sandoval-Peraza, M., Betancur-Ancona, B., \& ChelGuerrero, L. (2018). Physicochemical and reological properties of gum from Guazuma ulmifolia seeds. Transylvanian Review, 34(26), 8569-8575.

Association of Official Analytical Chemists - AOAC. (2005). Official methods of analysis of AOAC International (18th ed.). Washington: AOAC International.

Bajpai, S. K., \& Sharma, S. (2004). Investigation of sweeling/degradation behaviour of alginate beads crosslinked with $\mathrm{Ca}^{2+}$ and $\mathrm{Ba}^{2+}$ ions. Reactive \& Functional Polymers, 59(2), 129-140. http://dx.doi. org/10.1016/j.reactfunctpolym.2004.01.002.

Bauchart-Thevret, C., Stoll, B., \& Burrin, D. G. (2009). Intestinal metabolism of sulfur amino acids. Nutrition Research Reviews, 22(2), 175-187. http://dx.doi.org/10.1017/S0954422409990138. PMid:19835653.

Bayer, C. L., Herrero, É. P., \& Peppas, N. A. (2011). Alginate films as macromolecular imprinted matrices. Journal of Biomaterials Science. Polymer Edition, 22(11), 1523-1534. http://dx.doi. org/10.1163/092050610X514115. PMid:20633323.
Betancur-Ancona, D., Gallegos-Tintoré, S., \& Chel-Guerrero, L. (2004). Wet-fractionation of Phaseolus lunatus seeds: partial characterization on starch and protein. Journal of the Science of Food and Agriculture, 84(10), 1193-1201. http://dx.doi.org/10.1002/jsfa.1804.

Chan, E.-S., Wong, S.-L., Lee, P.-P., Lee, J.-S., Ti, T. B., Zhang, Z., Poncelet, D., Ravindra, P., Phan, S.-H., \& Yim, Z.-H. (2011). Effects of starch filler on the physical properties of lyophilized calcium-alginate beads and the viability of encapsulated cells. Carbohydrate Polymers, 83(1), 225-232. http://dx.doi.org/10.1016/j.carbpol.2010.07.044.

Chel-Guerrero, L. A., Domínguez-Magaña, M., Martínez-Ayala, A., Dávila-Ortiz, G., \& Betancur-Ancona, D. (2012). Lima Bean (Phaseolus lunatus) protein hydrolisates with ACE-I inhibitory activity. Food and Nutrition Sciences, 3(4), 511-521. http://dx.doi. org/10.4236/fns.2012.34072.

Cho, M. J., Unklesbay, N., Hsieh, F., \& Clarke, A. D. (2004). Hydrophobicity of bitter peptides from soy protein hydrolysates. Journal of Agricultural and Food Chemistry, 52(19), 5895-5901. http://dx.doi.org/10.1021/ jf0495035. PMid:15366839.

de la Vara Salazar, R., \& Gutiérrez Pulido, H. (2008). Optimización simultánea de varias respuestas. In R. de la Vara Salazar \& H. Gutiérrez Pulido (Eds.), Análisis y diseño de experimentos (2. ed., pp. 432-446). México, D.F.: McGraw Hill.

Dickinson, E. (2009). Hydrocolloids as emulsifiers and emulsion stabilizers. Food Hydrocolloids, 23(6), 1473-1482. http://dx.doi. org/10.1016/j.foodhyd.2008.08.005.

Intiquilla, A., Jiménez-Aliaga, K., Zavaleta, A. I., Arnao, I., Peña, C., Chávez-Hidalgo, E. L., \& Hernández-Ledesma, B. (2016). Erythrina edulis (Pajuro) seed protein: a new source of antioxidant peptides. Natural Product Communications, 11(6), 781. http://dx.doi. org/10.1177/1934578X1601100620. PMid:27534115.

Ishii, F., \& Nagasaka, Y. (2001). Simple and convenient method for estimation marker entrapped in liposomes. Journal of Dispersion Science and Technology, 22(1), 97-101. http://dx.doi.org/10.1081/ DIS-100102684.

Jaya, S., Durance, T. D., \& Wang, R. (2009). Effect of alginate-pectin composition on drug release characteristics of microcapsules. Journal of Microencapsulation, 26(2), 143-153. http://dx.doi. org/10.1080/02652040802211345. PMid:18615289.

Kang, H. W., Tabata, Y., \& Ikada, Y. (1999). Fabrication of porous gelatin scaffolds for tissue engineering. Biomaterials, 20(14), 1339-1344. http://dx.doi.org/10.1016/S0142-9612(99)00036-8. PMid:10403052.

Kim, J. M., Liceaga, A. M., \& Yoon, K. Y. (2019). Purification and identification of an antioxidant peptide from perilla seed (Perilla frutescens) meal protein hydrolysate. Food Science \& Nutrition, 7(5), 1645-1655. http://dx.doi.org/10.1002/fsn3.998. PMid:31139377.

Lowry, O. H., Rosebrough, N. J., Farr, A. L., \& Randall, R. J. (1951). Protein measurement with the folin phenol reagent. The Journal of Biological Chemistry, 193(1), 265-275. http://dx.doi.org/10.1016/ S0021-9258(19)52451-6. PMid:14907713.

Lundquist, P., \& Artursson, P. (2016). Oral absorption of peptides and nanoparticles across the human intestine: opportunities, limitations and studies in human tissues. Advanced Drug Delivery Reviews, 106(Pt B), 256-276. http://dx.doi.org/10.1016/j.addr.2016.07.007. PMid:27496705.

Manríquez, M. L., Yalid, L., López, O. S., Pérez, H. P., Ortega, J. E., López-Tecpoyotl, Z. G., \& Villarruel-Fuentes, M. (2011). Agronomic and forage characteristics of Guazuma ulmifolia Lam. Tropical and Subtropical Agroecosystems, 14, 453-463.

Montgomery, D. (2017). Design and analysis of experiments (9th ed.). New York: John Wiley \& Sons. 
Nielsen, P. M., Petersen, D., \& Dambmann, C. (2001). Improved method for determining food protein degree of hydrolysis. Journal of Food Science, 66(5), 642-648. http://dx.doi.org/10.1111/j.1365-2621.2001. tb04614.x.

Polanco-Lugo, E., Dávila-Ortiz, G., Betancur-Ancona, D., \& ChelGuerrero, L. (2014). Effects of sequential enzymatic hydrolysis on structural, bioactive and functional properties of Phaseolus lunatus protein isolate. Food Science and Technology, 34(3), 441-448. http:// dx.doi.org/10.1590/1678-457x.6349.

Pukalskas, A., van Beek, T. A., Venskutonis, R. P., Linssen, J. P., van Veldhuizen, A., \& de Groot, A. (2002). Identification of radical scavengers in sweet grass (Hierochloe odorata). Journal of Agricultural and Food Chemistry, 50(10), 2914-2919. http://dx.doi.org/10.1021/ jf011016r. PMid:11982419.

Rodríguez, S. J. A., Cuatzo, L. M. I., Pérez, L. M. G., Abaca, S. D. I., \& Gallardo, N. Y. (2017). Alginate encapsulation as a preservation method of pitaya fruit juice (Stenocereus spp.). Journal of Food Science and Engineering, 7(3), 127-134. http://dx.doi.org/10.17265/21595828/2017.03.002.

Ruiz-Ruiz, J., Dávila-Ortíz, G., Chel-Guerrero, L., \& Betancur-Ancona, D. (2013). Angiotensin I-converting enzyme inhibitory and antioxidant peptide fractions from hard-to-cook bean enzymatic hydrolysates. Journal of Food Biochemistry, 37(1), 26-35. http:// dx.doi.org/10.1111/j.1745-4514.2011.00594.x.

Sandoval-Peraza, M. (2015). Microencapsulation of hydrolyzed proteins from Phaseolus lunatus L. with flamboyant (Delonix regia bojer) and chia (Salvia hispanica L.) gums (Ph.D. thesis). Mérida: Universidad Autónoma de Yucatán.

Sandoval-Peraza, M., Betancur-Ancona, D., Gallegos-Tintoré, S., \& Chel-Guerrero, L. (2014). Evaluation of some residual bioactivities of microencapsulated Phaseolus lunatus protein fraction with carboxymethylated flamboyant (Delonix regia) gum/sodium alginate. Food Science and Technology, 34(4), 680-687. http://dx.doi. org/10.1590/1678-457X.6425.

Sandoval-Peraza, M., Acevedo-Fernández, J.J., Castañeda-Corral, G., Santa-Olalla, J., Betancur-Ancona, D., Chel-Guerrero, L. (2019). Evaluation of the native gum of Guazuma ulmifolia for encapsulation of peptide fractions with ACE inhibitory activity. JONNPR, 4(8), 774-784. DOI: 10.19230/jonnpr.3007.

Sarabandi, K., Gharehbeglou, P., \& Jafari, S. M. (2020). Spray-drying encapsulation of protein hydrolysates and bioactive peptides: opportunities and challenges. Drying Technology, 38(5-6), 577-595. http://dx.doi.org/10.1080/07373937.2019.1689399.
Sarabandi, K., Rafiee, Z., Khodaei, D., \& Jafari, S. M. (2019). Encapsulation of food ingredients by nanoliposomes. In S. M. Jafari (Eds.), Lipidbased nanostructures for food encapsulation purposes (Vol. 2, pp. 347-404). London: Elsevier. http://dx.doi.org/10.1016/B978-0-12815673-5.00009-X.

Segura-Campos, M., Chel-Guerrero, L., Betancur-Ancona, D., \& Hernández-Escalante, V. M. (2011). Bioavailability of bioactive peptides. Food Reviews International, 27(3), 213-226. http://dx.doi. org/10.1080/87559129.2011.563395.

Segura-Campos, M., Ruiz-Ruiz, J., Chel-Guerrero, L., \& BetancurAncona, D. (2013). Antioxidant activity of Vigna unguiculata L. walp and hard-to-cook Phaseolus vulgaris L. protein hydrolysates. CYTA: Journal of Food, 11(3), 208-215. http://dx.doi.org/10.1080/ 19476337.2012.722687.

Silva, P. T., Fries, L. L. M., Menezes, C. R., Holkem, A. T., Schwan, C. L., Wigmann, É. F., Bastos, J. O., \& Silva, C. B. (2014). Microencapsulation: concepts, mechanisms, methods and some applications in food technology. Ciência Rural, 44(7), 1304-1311. http://dx.doi.org/10.1590/0103-8478cr20130971.

Stojanovic, R., Belscak-Cvitanovic, A., Manojlovic, V., Komes, D., Nedovic, V., \& Bugarski, B. (2012). Encapsulation of thyme (Thymus serpyllum $\mathrm{L}$.) aqueous extract in calcium alginate beads. Journal of the Science of Food and Agriculture, 92(3), 685-696. http://dx.doi. org/10.1002/jsfa.4632. PMid:21953367.

Takagi, K., Teshima, R., Okunuki, H., \& Sawada, J. (2003). Comparative study of in vitro digestibility of food proteins and effect of preheating on the digestion. Biological \& Pharmaceutical Bulletin, 26(7), 969973. http://dx.doi.org/10.1248/bpb.26.969. PMid:12843620.

Xia, Y., Bamdad, M., Gänzle, M., \& Chen, L. (2012). Fractionation and characterization of antioxidant peptides derived from barley glutelin by enzymatic hydrolysis. Food Chemistry, 134(3), 1509-1518. http://dx.doi.org/10.1016/j.foodchem.2012.03.063. PMid:25005974.

Yellavila, S. B., Agbenorhevi, J. K., Asibuo, J. Y., \& Sampson, G. O. (2015). Proximate composition, minerals content and functional properties of five Lima bean accessions. Journal of Food Security, 3(3), 69-74. http://dx.doi.org/10.12691/jfs-3-3-1.

Yeo, Y., Baek, N., \& Park, K. (2001). Microencapsulation methods for delivery of protein drugs. Biotechnology and Bioprocess Engineering, 6(4), 213-230. http://dx.doi.org/10.1007/BF02931982.

Yust, M. M., Pedroche, J., Girón-Calle, J., Alaiz, M., Millán, F., \& Vioque, J. (2003). Production of ACE inhibitory peptides by digestion of chickpea legumin with alcalase. Food Chemistry, 81(3), 363-369. http://dx.doi.org/10.1016/S0308-8146(02)00431-4. 